\title{
Organizational Commitment and Job Performance: Examining the Mediating and Moderating Roles of Organizational Citizenship Behaviour and Leadership Styles
}

\author{
ERIC COBBINAH (Corresponding Author) \\ School of Management, Jiangsu University, \\ Zhenjiang, 212013, China \\ E-mail: cobb2eric@gmail.com
}

\author{
ALBERT HENRY NTARMAH \\ School of Finance and Economics, Jiangsu University, \\ Zhenjiang, 212013, China \\ E-mail: henritoalberto@gmail.com
}

ANTHONY FRANK OBENG

School of Management, Jiangsu University,

Zhenjiang, 212013, China

E-mail: turksoo1@yahoo.com; 5103181239@stmail.ujs.edu.cn

\section{PRINCE EWUDZIE QUANSAH}

School of Management, Jiangsu University,

Zhenjiang, 212013, China

E-mail: dr.peq1986@yahoo.com; 5103181227@stmail.ujs.edu.cn

Received: Sep. 8, 2020 Accepted: Oct. 17, 2020 Online published: Oct. 27, 2020

doi:10.5296/ijhrs.v10i4.17660ＵRL: https://doi.org/10.5296/ijhrs.v10i4.17660 


\section{Abstract}

Though a significant number of studies in organizational behaviour literature have shown a positive relationship between affective organizational commitment and job performance, the findings of some studies indicate that the relationship varies. This highlights the presence of mediator and moderator variables. Our study seeks to clarify when and why affective organizational commitment is more or less related to job performance by investigating the mediating role of organizational citizenship behaviour and the moderating effect of leadership styles (transactional and transformational) on this relationship. Using a quantitative survey we sampled 556 workers from the Metropolitan, Municipal and District Assemblies in Ghana. The empirical results from hierarchical multiple linear regressions showed a positive relationship between affective commitment and job performance whilst OCB also mediated this relationship. The moderation analysis revealed that leadership styles (transformational and transactional) strengthened the positive relationship between affective commitment and job performance with transactional leadership the most effective leadership style. The outcome of our study suggest that, though affective commitment positively relates with job performance the relationship varies with the leader's leadership style. We realized that within the local government context in Ghana, organizational commitment is more closely or strongly related to job performance when leaders (MMDCEs/mayors) transactional rather than transformational leadership is high. The practical contributions of this study are thoroughly discussed.

Keywords: affective commitment, organizational citizenship behaviour, job performance, leadership style, transactional and transformational leadership, metropolitan, municipal and district assemblies

\section{Introduction}

All over the world, governments are making concerted efforts in ensuring sustainable development that brings both qualitative and quantitative improvements in the lives of the people with the ultimate objective of alleviating poverty. According to Adams (2012) one major strategy adopted by most developing countries to bring development closer to the grassroots and reduce poverty is decentralized governance. In Ghana, adequate provision has been made for local governance and decentralization that provides the platform for effective participation for her citizens_ in decision-making at the grass root level. Ghana's local government framework thus directs the Metropolitan, Municipal and District Assemblies (MMDAs) to mobilize resources within their catchment area, formulate and implement policies for the total development of their local areas (Ahwoi, 2010).

However, for any institution to achieve its ultimate organizational objective highly motivated and committed employees are required and the MMDAs in Ghana is not an exception. According to Jamal (2011) employees' commitment positively correlates with their motivation and effort which mostly results in improved performance. The importance of organizational commitment (OC) especially the affective dimension towards enhanced employee performance largely explains why organizational commitment is one of the widely investigated variables in organizational literature (Mathieu \& Zajac, 1990; Meyer \& Allen, 
1997) and still focuses the attention of organizational scholars (Klein et al, 2014; Klein et al, 2012; Reader et al, 2017; Sungu, Weng, \& Xu, 2019).

According to Kehoe \& Wright (2013) affective commitment (AC) is demonstrated through the positive affection and the desire of the individual to see to the successful accomplishment of organizational goal and a sense of pride in being a member of the organization. According to Azeem (2010) and Al Zeifeti\& Mohamad (2017) a deep interest in corporate values and goals, a willingness to make a great deal of effort on behalf of the company and a genuine desire to be a part of the organization would encourage employees to perform better. Available studies revealed that organizational commitment (OC) is related to job performance (Irefin \& Mechanic, 2014; Bandula \& Jayatilake, 2016; Hendri, 2019; Sungu et al 2019)as well as organizational citizenship behaviour (Rahman \& Karan, 2011). According to Rahman \& Karan (2011) OCB serves as a mechanism through which OC influences JP.

Organ (1988) defined OCB as a voluntary employee conduct, with no recognition in relation to the organizations formal reward system but contributes significantly to the achievement of the organizational vision. According to Robins \& Judge (2009) OCB is a "discretionary behaviour that is not a part of an employee's formal job requirements, but that nevertheless promotes the effective functioning of the organization". Some studies have shown a positive relationship between the conduct of OCB and JP (Mallick et. al, 2014; Al-Mahasneh, 2015; Basu et al 2017 and Barsulai et al, 2019). In our research, we use OCB as a mediator to gain a better understanding of the process by which AC affects JP of employees.

Meyer, Becker, \&Vandenberghe (2004) postulate that the relationship between OC and JP is heterogeneous in nature. They argue that: (1) the effect of OC on JP may be as a result of commitment to other foci which affects employee goal and (2) contextual factors moderates the effect of organizational commitment. Consistent with this theoretical forecast, we propose a model in which leadership styles (transformational TFL and transactional TSL) are viewed as moderators.

While a few studies have emerged assessing the moderating effects of transformational and transactional leadership styles on organizational outcomes (Lee and Wei, 2017; Sungu, Weng, $\& \mathrm{Xu}, 2019)$, hardly had any empirical research in extant literature examined the moderating effects of TFL and TSL on organizational commitment and job performance relationship in Ghana. Most of the studies that assessed the moderating effects of TFL and TSL on organizational outcomes were done in Western and Asian countries which have different organizational environment and national culture from the unique Ghanaian context that the Metropolitan, Municipal and District Assemblies (MMDAs) operate. This study therefore will fill the gap in existing literature by providing empirical evidence whether TFL and TSL moderate AC and JP relationship in the Ghanaian context and the type of leadership style that better moderates this relationship.

We therefore focus on these two potential moderators to assess their effect on employee commitment and performance within the organizational environment of the MMDAs in Ghana. 
Based on the above, our objectives are as follows: (a) to find out the influence of AC on the JP of employees; (b) determine whether or not OCB serves as mediator in the AC-JP relationship; and (c) to explore the moderating effects of LDS (TFL and TSL) on the relationship between AC and JP.

\section{Literature and Hypotheses Development}

\subsection{Affective Commitment (AC) and Job Performance (JP)}

Organizational commitment (OC) remains one of the essential organizational behavioural construct that has gained significant attention from researchers. According to Yavuz (2010) organizational commitment is fundamental to the maintenance and existence of an institution. In that it is crucial to the successful accomplishment of the overall organizational goal. According to Meyer and Allen (1997) researchers in organizational studies mostly acknowledge three types of commitment. They argue that the commitment of the employee to an institution or organization is born out of an obligation, necessity and inner desire to safeguard and maintain a relationship. As a result, commitment can be categorized into affective, normative and continuance which has become the generally accepted three distinctive types of commitment in literature.

Affective commitment (AC): relates to inner connection, emotional attachment of the worker towards the institution which is demonstrated with deep identification and involvement in organizational activities. Normative commitment (NC): under this commitment type, a sense of moral obligation is demonstrated by the employee to remain part of the organization.

Continuance Commitment (CC): here an employee decides to commit to the organization after doing a comprehensive socio-economic cost benefit analysis of staying and leaving the organization. However, Meyer and Allen (1991) report that AC and NC are positive predictors of performance than $\mathrm{CC}$ which may not have significant effect on performance or even negatively affect it (Meyer, Allen, \& Smith, 1993). However, they further argue that AC is a better predictor of performance than NC. In this research, we use AC to assess its effect on JP.

Sharma, Borna, and Stearns (2009) described job performance (JP) as an outcome associated with work done which is measured by performance assessment on job-related responsibilities assigned to the employee with the ultimate objective of achieving the organizational goal. Job performance (JP) within the context of a public institution refers to specific tasks or assignments executed within a standard unit of time by an employee of a public institution that contributes to the achievement of organizational objective.

Several research workers in organizational behaviour literature show that organizational commitment (OC) in general has positive effect on JP (Rahman \& Karan, 2011; Irefin \&Mechanic, 2014; Bandula \& Jayatilake, 2016; Hendri, 2019; Sungu, Weng, \& Xu, 2019). According to Demirel and Goc (2013) employees who are dedicated to their institutions are very productive, loyal to their work and responsible in their line of duty which is a competitive advantage to the institution. Riketta (2002) reported a positive relationship between AC and JP in a meta-analysis which included sample of nurses. Khan et al. (2010) in 
a study of the three dimensions of OC identified a strong relationship between OC and JP of employees. Furthermore, Hafiz (2017) showed a significant relationship between affective commitment (AC), normative commitment (NC) and continuance commitment (CC) and employee performance. Sungu, Weng, \& Xu (2019) in a study that examined the moderating roles of occupational commitment and transformational leadership on the relationship between AC and JP concluded that AC generally positively relate to JP but the relationship varies with the employees OC and supervisor's leadership style. We therefore hypothesized that:

H1: Affective commitment (AC) positively relates with job performance (JP)

\subsection{Organizational Citizenship Behaviour $(O C B)$ as a Mediator}

OCB is a widely researched attitudinal and behavioural construct in organizational studies since the term was coined in the 1980s. When an employee of an organization identifies himself as a 'citizen' of that institution like a citizen of a country, that employee willingly undertakes activities that inure to the benefit of the organization. These type of employees are willing and ready to go beyond their line of duty to ensure that their organization succeeds.

Abu (2012) defined OCB as "a voluntary behaviour practiced by employee without expecting any reward or material incentives so as to promote the organization. It is an inner feeling of responsibility that motivates the individual to work voluntarily in order to accomplish the ambitions of organization". From the forgoing it can be deduced that OCB is a voluntary action which warrants no reward when an employee undertakes and has no punitive measures when it's not done. This behaviour therefore promotes efficiency, effectiveness and employee job performance. In an essential public institution like the MMDAs which serve as the conduit for poverty alleviation at the local level, such employee behaviours are required to ensure that the MMDAs achieve their objective of bringing development closer to the people.

According to Organ (1988) OCB can be classified into five dimensions namely: (a) altruism; assesses the zeal, willingness that employees voluntarily offer to assist in finding solutions to a problem or task at the workplace;(b) courtesy component of $\mathrm{OCB}$, is exhibited through respect for co-workers, personal attitude that gives special attention to colleagues, and basic considerations to others; (c) sportsmanship dimension is a reflection of an employee's ability to be tolerant and accommodate dissenting views and the inevitable inconveniences at work. One shows citizenship akin to uncomplaining attitude; (d) conscientiousness; refers to a situation in which workers perform their duties well above the minimum required standards, such as attending required meetings, keeping the work area clean, timeliness and adherence to certain formal and informal rules designed to preserve order in the workplace; (e) civic virtue/corporate social responsibility; looks at the responsible participation of the employee in organizational activities i.e. part taking in organizational sponsored events.

A number of theoretical and empirical studies in organizational behaviour literature have alluded to the positive relationship between OC and OCB because scholars argue that workers who are dedicated and committed to their job most often exhibit positive behaviours that support the organization in achieving its objectives. Theoretically, the social exchange 
theory (Blau, 1964) gives credence to the positive correlation between OC and OCB and thus serves as the theoretical foundation for this relationship. According to Cohen \&Keren (2008) based on the concept of reciprocity, workers will show more commitment and dedication by even going beyond their assigned task (exhibit citizenship behaviour) as a form of appreciation to their organization when they experience positive exchanges with their organization.

Organ \& Ryan (1995) and LePine et al. (2002) consistent with this theoretical and empirical argument, reported that there is a correlation between AC and OCB. Zehir, Muceldili, \&Zehir(2012) further supported this findings by suggesting that workers who manifest deep AC voluntarily engage in organizational activities because they have an emotional attachment towards their organization. Moreover, a significant number of studies in extant literature (Salehi\&Gholtash, 2011; Benjamin, 2012; Cohen, Ben-Tura, \&Vashdi, 2012; De Lara \& Rodriguez, 2007; Ucanok\&Karabati, 2013; Xerri\&Brunetto, 2013) have reported the positive influence of $\mathrm{OC}$ on $\mathrm{OCB}$ and established the connection between these variables. Also,Grego-Planer (2019) in a study that investigated the relationship between OC and OCB in Poland reported general similarities in frequencies of OCB in both public and private sectors.Nevertheless, OCBs in the interpersonal dimension were more prevalent in public institutions, while they occur more frequently in the organizational dimension in private institutions. The study however found AC to be the most positively correlated predictor with OCBs. Supporting and establishing this connection in the Ghanaian context, we propose that:

H2: Affective commitment (AC) relates positively with $\mathrm{OCB}$

It is argued that OCB is an essential ingredient for employee effective task performance. The significance of OCB towards effective and efficient functioning of the organization has led to many research works with the objective of studying its antecedents and consequences at both personal and the institutional level (Podsakoff et al., 2000). Many studies in literature show that OCB positively predict employee and organizational performance (Malik et al 2014; Organ, Podsakoff, \&MacKenzie, 2006; Barsulai, Makopondo, \&Fwaya, 2019). According to Podsakoff et al. (2000) and Whiting, Podsakoff, \& Pierce (2008) though OCB is not part of the normal work schedule of an employee, it reflects and influences how management assesses the performance of employees. Organ, Podsakoff, \&MacKenzie (2006) thus argue that a strong belief exists on the part of leaders that OCB has positive effect on the organization especially on performance and that workers who show such discretionary behaviour are seen as being dedicated and committed to the organization.

Nasir et al. (2011) examined the effect of gender, age, education and tenure on the relationship between $\mathrm{OCB}$ and JP and concluded that there was a substantial connection between OCB and JP, and that the relationship between OCB and JP was moderated by gender and education. Also, Al-Mahasneh (2015) investigated the effect of OCB on JP in Amman Greater Municipality and concluded that OCB positively impact on JP. Furthermore, Basu et al. (2017) studied the impact of OCB on JP and the mediating role of social capital. The results of the study showed that OCB predicts JP. Social capital also mediated the relationship between OCB and JP. On the basis of the above we hypothesize that: 
H3: OCB relates positively with job performance (JP)

Though the connection between $\mathrm{OC}$ and $\mathrm{OCB}$ is supported theoretically and empirically, there is also enough evidence about the positive relationship between OCB and JP which further strengthens the argument that OCB serves as a mediator between OC and JP. In other words, scholars have demonstrated that OC correlates with OCB and OCB does same with JP.Rahman \& Karan (2011) reported a positive correlation between OC and JP in a study that explored the mediating function of OCB at various organizations in Chittagone. In addition, OCB was found to completely mediate OC's relationship with JP. We therefore hypothesize that:

H4: OCB mediates the relationship between affective commitment (AC) and job performance (JP)

\subsection{The Moderating Effect of Leadership Styles (Transformational and Transactional)}

Leadership style plays a major role in shaping how workers view their working environment as being conducive and supportive to their JP (Sungu, Weng\& Xu 2019). Landrum, et al. (2000) argues that effective leaders monitor and direct their employees towards the accomplishment of specific organizational goals and objectives. When challenges and problems become rampant good leaders are able to provide effective leadership by guiding their workers and putting in place good measures to address such impediments in difficult moments (Grojean, et al., 2004). House (1995) defined leadership as a behaviour "that gives purpose, meaning, and guidance to collectivities by articulating a collective vision that appeals to ideological values, motives, and self-perceptions of followers." House further notes that the outcome of such actions are increased knowledge of organizational principles, unprecedented levels of commitment and the avoidance of followers self-interest for the collective good.

Transformational (TFL) and transactional (TSL) leadership styles dominate modern day theory of leadership. Burns (1978) first proposed these concepts and Bass and Avolio expanded them to incorporate the "full range model of leadership" (Bass, 1985; Bass, 1999; Avolio and Bass, 1991; Bass and Avolio, 1993). Transformational leaders strive to encourage and inspire workers to support the organization's goals and values beyond the normal expected rewards. They encourage and motivate followers to surpass standard performance levels (Bass, 1985; Bass \&Riggio, 2006; Wang \& Rode, 2010; Yukl, 1999; Vigoda-Godat, 2007). Bass (1985) argues that transformative leadership pushes "the follower beyond immediate self-interest through idealized influence (charisma), inspiration, intellectual stimulation, or individualized consideration". Bass \&Riggio (2006) postulate that individuals who possess TFL style motivate their subordinates to go beyond the short-lived and limited desires for the purposes that are in the organization's best interest. Earlier research findings have reported a positive correlation between TFL and employee performance (Geyer and Steyrer, 1998; Lowe et al., 1996; MacKenzie et al., 2001; Parry, 2003; Pillai et al., 1999;Vigoda-Godat, 2007). Consequently, Meyer, Becker \&Vandenberghe (2004) assert that TFL presents an essential context for assessing the influence of organizational commitment (OC) on employee JP. 
However, under transactional leadership (TSL) the leader goes into negotiation with subordinates and agrees on the incentives, pecks, specific reward or recognition to be given to the employees for accomplishing a particular task. The leader as part of the contractual agreement provides the rewards or recognition as well as the pecks or incentives when acceptable or agreed upon performance levels are achieved (Judge \& Piccolo, 2004; Si \& Wei, 2012). According to Waldman, Bass, \& Yammarino (1990) leaders with TSL traits reward their subordinates for achieving certain level of performance. A number of previous studies have shown that TSL has significant positive effect on subordinate satisfaction and performance (Podsakoff et al., 1984; Podsakoff et al., 1982; Lee \& Wei, 2008). From the forgoing, it possible that some leaders can be viewed as unjust in the incentive or reward distribution process and ultimately can affect their followers' morale and commitment. Thus, exploring the intervening leadership processes, not just transformative but transactional leadership, on the connection between AC and JP relationship is worthwhile.

Lee and Wei (2017) studied the effects of employee perceptions of organizational justice on $\mathrm{AC}$, and the moderating influence of leadership styles on the relationship, and concluded that LDS in teams moderates the relationship between interactional justice and AC. Sungu, Weng\& Xu (2019) examined the moderating roles of occupational commitment and TFL on $\mathrm{AC}$ and JP relationship in China. The study findings revealed that AC was more closely correlated with JP for workers with high occupation commitment, or when TFL was high for a supervisor. In a moderated mediation relationship, they indicated that TFL's effect on the relationship between $\mathrm{AC}$ and JP for workers with high occupational commitment was contrary to its effect on employees with low occupational commitment. Thus employees would experience a more supportive working environment under an effective leader who shows stronger leadership than others who are incapable of doing so.

In the context of the MMDAs in Ghana, we argue that MMDCEs (Mayors) exhibiting good leadership styles both transformative and transactional will have highly committed workers in order to achieve high performance within the MMDAs. According to Wright \& Bonett (2002) workers with low commitment have no incentives which encourage them to put in their best for the benefit of the organization. However, it must be emphasized that majority of research works on the leadership-performance relationship indicate a stronger connection between TFL and performance compared to TSL and performance (MacKenzie et al., 2001; Vigoda-Godat, 2007). We therefore, posit that

H5: Leadership styles (TFL and TSL) moderates the positive relationship between affective commitment (AC) and job performance (JP) such that the relationship is stronger when the leaders TFL rather than TSL style is high.

\section{Conceptual framework}

We hypothesized that AC will have positive effect on JP. We also expect OCB to act as an intervening variable to help us understand better the mechanism through which AC affects the JP of employees. The conceptual model also has transformational (TFL) and transactional (TSL) leadership styles as moderators. This is to help us assess their moderating effect (TFL and TSL) on AC and JP relationship. Figure 1 below shows the conceptual framework and the 


\section{Macrothink \\ International Journal of Human Resource Studies \\ ISSN 2162-3058 2020, Vol. 10, No. 4}

hypothesized relationships.

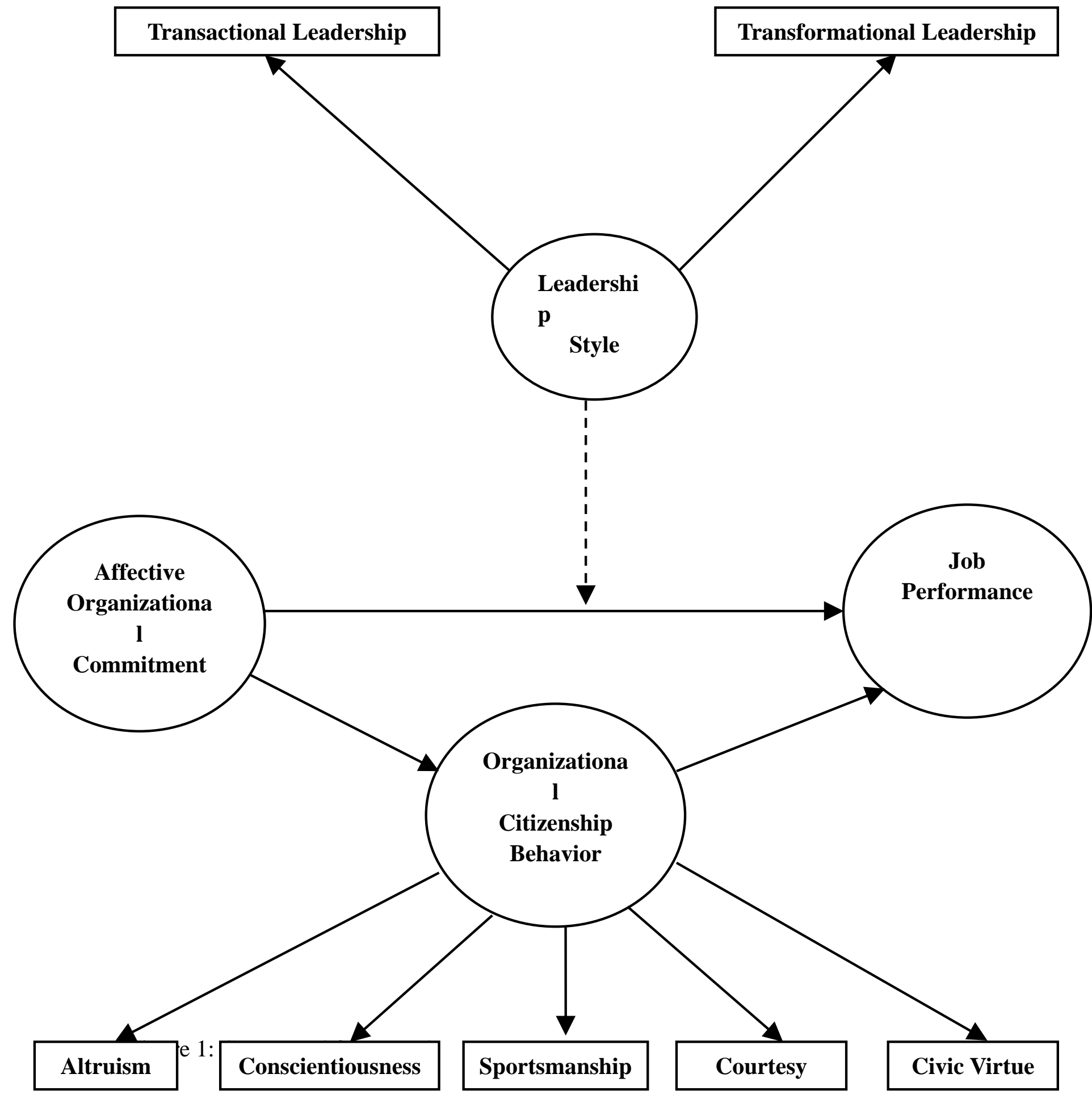




\section{Materials and Methods}

\subsection{Participants, Sample and Procedures}

The participants for this study are employees from 14 Metropolitan, Municipal and District Assemblies (MMDAs) located in western region of Ghana. They comprise Metropolitan, Municipal and District Chief Executives (MMDCEs/mayors), Heads of Department (HOD), middle and junior staff from 16 departments within the MMDAs. Given the sample's complex nature, we used multi-stage sampling method (three main stages). First simple random sampling to select 8 MMDAs out of 14 , secondly proportionate sampling to select proportional sample from each of the selected MMDAs and finally since the MMDAs are made up of departments proportionate sampling is used to select the representatives of each department. A total of 730 serial numbered questionnaires were distributed to the respondents from which we obtained 556 usable questionnaires, a response rate of about $76 \%$. Of the 556 participants surveyed for the study, $1.62 \%$ were MMDCEs, $20.14 \%$ were HODs, $47.66 \%$ were middle management staff and $30.58 \%$ were junior workers. Males accounted for $56.47 \%$, while females accounted for $43.53 \%$. Additionally, $14.93 \%$ were 30 years or below, $35.07 \%, 32.91 \%$ and $17.09 \%$ were between 31-40years, 41-50years and 51-60 years respectively. Furthermore, $2.16 \%$ had no formal education while $8.09 \%, 15.83 \%$ and $73.92 \%$ had basic, secondary and tertiary education respectively. As regards the type of MMDAs, 39.75\% of the participants were from the district assemblies, 39.39\% from municipal assemblies and $20.86 \%$ from metropolitan assemblies.

\subsection{Measures}

The questionnaire for the study had four components based on extensive literature review. Affective commitment (AC) was measured using a scale adapted from Meyer and Allen (1997). Respondents completed six questions from this scale. The measure is extensively used in earlier research works and incorporate much of the content of Organizational Commitment Questionnaire (Mowday, Steers, \& Porter, 1979) and Meyer and Allen's (1991) Affective Commitment Scale (Flynn \& Schaumberg, 2012; Mueller et al., 2012).Lee and Wei (2017) using the AC scale reported the coefficient alpha of .88.Job performance was measured with a 7-item scale developed by Williams and Anderson (1991).Sungu, Weng\& $\mathrm{Xu}$ (2019) using this scale reported Cronbach's alpha of 0.89. Podsakoff et al. (1990) OCB scale was used to measure Organizational citizenship behaviour. The scale has 24 items measuring the different dimensions of OCB such as altruism 5 items, conscientiousness 5 items, courtesy 5 items, sportsmanship 5 items, and civic virtue 4 items. Basu, Pradhan and Tewari (2017) reported a Cronbach's alpha of 0.90 when using the scale. Leadership stylewas measured with a scale adapted from Bass and Avolio (2000) simplified version of Multifactor Leadership Questionnaire (MLQ) Form 5X. The scale comprised of 24 items measuring transformational (TFL) and transactional leadership (TSL); 15 for TFL and 9 for TSL. We asked respondents to determine how often they were involved in specific behaviours measured by the scale. Sungu, Weng\& Xu (2019) using the MLQ 5X scale reported Cronbach's alpha of $0.90 . \& 0.87$ for TFL and TSL respectively. 


\section{Macrothink}

These instruments were adopted due to the following factors: (a) they are supported by empirical and theoretical literature: (b) they are widely and generally accepted as valid and reliable in measuring the variables of interest to the study: and (c) they address the multifaceted nature of the variables used for the study. All the instruments were measured on a 5-point Likert scale

\section{Data Collection}

We employed repeated cross-sectional approach with three phases to obtain comprehensive and reliable data. To be able to ensure consistency and proper integration of the data, we coded each of the questionnaires. Each of the distributed questionnaires had the sampled MMDAs and specific departments/units codes. For instance, codes 010201 represented respondent one (01) from finance department (02) of MMDA one (01) and 030101 represented respondent one (01) from central administration (01) of MMDA three (03) respectively. The same codes were given to the three sets of questionnaires for the three phases. We collected data on AC and JP during phase one of data collection. Whilst data on OCB and LDS (TFL \& TSL) were collected during phase two and three respectively. During the first phase, respondents were encouraged to keep their codes. This helped for easy distribution of questionnaires in phases two and three. Approximately, we used five months to collect the data with roughly one-month interval after each phase. Ethical issues were considered particularly through the use of informed consent approach and confidentiality of participants.

\subsection{Procedure}

We followed series of estimation procedures to arrive at valid and reliable results. In the first place, we screened the questionnaires and integrated the data from the three phases to become a complete dataset for each of the participants. Using excel sorting and data screening approach, we further crosschecked the data with the demographic characteristics of the participants reported at each phase of data collection. We also performed descriptive statistics such as frequencies and percentages to support the preliminary analysis. Secondly, we used STATA software version 15.0 to establish the consistency and stability of the data by calculating the coefficient of the fractal dimension. Thirdly, we used AMOS software version 22.0 to determine the validity and reliability of the scales by conducting confirmatory factor analyses (CFA), composite reliability (CR) and average variance extracted (AVE). Fourthly, we performed correlation analysis to verify the association among the variables as a preliminary step to provide prior support for the hypotheses. Finally, yet importantly, we used hierarchical regression estimation procedure through STATA software to test the hypotheses formulated for the study. 


\section{Ml Macrothink \\ International Journal of Human Resource Studies \\ ISSN 2162-3058 2020, Vol. 10, No. 4}

Table 1. Standardized Factor Loadings and T-Values

\begin{tabular}{llll}
\hline Construct & items & Standardized & $\begin{array}{l}\mathbf{t} \\
\text { value }\end{array}$ \\
\hline Affective Commitment & $\mathrm{AC} 1$ & 0.667 &
\end{tabular}

$\begin{array}{llll} & \text { AC2 } & 0.768 & 23.8 \\ \text { AC3 } & 0.689 & 20.35 \\ \text { AC4 } & 0.704 & 20.42 \\ & \text { AC5 } & 0.685 & 20.16 \\ \text { AC6 } & 0.719 & 21.99 \\ \text { Job Performance } & & & \\ & \text { JP1 } & 0.671 & \\ \text { JP2 } & 0.951 & 117.06 \\ \text { JP3 } & 0.944 & 112.99 \\ \text { JP4 } & 0.68 & 28.22 \\ \text { (Leadership Styles) } & \text { JP5 } & 0.757 & 32.38 \\ & \text { JP6 } & 0.667 & 25.58 \\ \text { JP7 } & 0.83 & 60.39 \\ \text { TSL1 } & 0.789 & \end{array}$

Transactional

Leadership Style

$\begin{array}{lll}\text { TSL2 } & 0.673 & 23.65 \\ \text { TSL3 } & 0.666 & 23.23 \\ \text { TSL4 } & 0.733 & 29.05 \\ \text { TSL5 } & 0.661 & 22.8 \\ \text { TSL6 } & 0.63 & 21.15 \\ \text { TSL7 } & 0.686 & 23.05 \\ \text { TSL8 } & 0.711 & 27.88 \\ \text { TSL9 } & 0.601 & 18.82 \\ \text { TFL1 } & 0.857 & \end{array}$

Transformational Leadership TFL1 0.857

Style

$\begin{array}{lll}\text { TFL2 } & 0.699 & 29.23 \\ \text { TFL3 } & 0.798 & 39.02 \\ \text { TFL4 } & 0.766 & 38.41 \\ \text { TFL5 } & 0.632 & 25.11 \\ \text { TFL6 } & 0.767 & 38.91 \\ \text { TFL7 } & 0.651 & 26.61 \\ \text { TFL8 } & 0.641 & 22.57 \\ \text { TFL9 } & 0.736 & 28.52 \\ \text { TFL10 } & 0.687 & 25.16\end{array}$


(OCB)

\begin{tabular}{|c|c|c|c|}
\hline \multirow[t]{5}{*}{ Altruism } & Alt1 & 0.609 & \\
\hline & Alt2 & 0.643 & 26.24 \\
\hline & Alt3 & 0.846 & 53.32 \\
\hline & Alt4 & 0.864 & 58.99 \\
\hline & Alt5 & 0.803 & 42.78 \\
\hline \multirow[t]{5}{*}{ Conscience } & Con 1 & 0.777 & \\
\hline & Con2 & 0.745 & 33.81 \\
\hline & Con 3 & 0.888 & 64.58 \\
\hline & Con4 & 0.747 & 34.11 \\
\hline & Con5 & 0.667 & 25.07 \\
\hline \multirow[t]{5}{*}{ Sports } & SP1 & 0.707 & \\
\hline & SP2 & 0.748 & 32.11 \\
\hline & SP3 & 0.689 & 25.6 \\
\hline & SP4 & 0.837 & 44.66 \\
\hline & SP5 & 0.768 & 34.43 \\
\hline \multirow[t]{5}{*}{ Courtesy } & Cou1 & 0.654 & \\
\hline & Cou2 & 0.72 & 28.8 \\
\hline & Cou3 & 0.868 & 50.61 \\
\hline & Cou4 & 0.725 & 29.8 \\
\hline & Cou5 & 0.658 & 22.97 \\
\hline \multirow[t]{4}{*}{ Civic } & CV1 & 0.905 & \\
\hline & $\mathrm{CV} 2$ & 0.835 & 52.09 \\
\hline & $\mathrm{CV} 3$ & 0.788 & 39.48 \\
\hline & CV4 & 0.777 & 38.79 \\
\hline
\end{tabular}

$\begin{array}{lll}\text { TFL11 } & 0.733 & 27.73 \\ \text { TFL12 } & 0.618 & 22.66 \\ \text { TFL13 } & 0.65 & 24.43 \\ \text { TFL14 } & 0.681 & 24.87 \\ \text { TFL15 } & 0.711 & 30.88\end{array}$

$(\mathrm{OCB})$

Altruism

Alt1 $\quad 0.609$

Alt 20.643

Alt3 0.846

53.32

Alt4

58.78

Conscience

SP1

0.707

SP3

0.689

25.6

SP4
SP5

0.837

44.66

34.43

Cou4 0.725

29.8

Cou $1 \quad 0.654$

Cou2

0.868

28.8

CV4

In addition, the average variance extracted (AVE) and the composite reliabilities (CR) values were greater than the generally accepted 0.70 and 0.50 respectively suggesting valid and reliable instruments used for the study given that both AVE and CR were above their threshold (see Table 2) (Gaskin and Lim, 2016). .In addition, the square root of the AVE values were higher than their inter-factor correlations providing further support for discriminant validity (Fornell and Larcker 1981; Gaskin and Lim, 2016). Furthermore, the 
CFA analysis using AMOS version 22.0 revealed the model fitness. Overall goodness of fits indices including comparative fit index was 0.966 , goodness-of-fit index was 0.953 , adjusted goodness-of-fit index was 0.940 , and root mean square error of approximation (RMSEA) was 0.051. Generally, the results follow the generally accepted fit indices and as such indicate a good fit of the model. This provides further support for analyzing the proposed hypotheses.

Table 2. Validity and Reliability Results

\begin{tabular}{|c|c|c|c|c|c|c|c|c|c|c|c|}
\hline & \multicolumn{3}{|c|}{$\mathrm{AV}$} & \multirow[b]{2}{*}{ TSL } & \multirow[b]{2}{*}{ TFL } & \multirow[b]{2}{*}{ ALT } & \multirow{2}{*}{$\begin{array}{l}\mathrm{CON} \\
\mathrm{S}\end{array}$} & \multirow{2}{*}{$\begin{array}{l}\text { SPOR } \\
\mathrm{T}\end{array}$} & \multicolumn{2}{|l|}{$\mathrm{COU}$} & \multirow[b]{2}{*}{ JP } \\
\hline & $\mathrm{CR}$ & $\mathrm{E}$ & $\mathrm{AC}$ & & & & & & $\mathrm{R}$ & CIV & \\
\hline & 0.75 & 0.51 & & & & & & & & & \\
\hline \multirow[t]{2}{*}{$\mathrm{AC}$} & 2 & 4 & .717 & & & & & & & & \\
\hline & 0.89 & 0.74 & -0.14 & & & & & & & & \\
\hline \multirow[t]{2}{*}{ TSL } & 3 & 8 & 7 & .865 & & & & & & & \\
\hline & 0.88 & 0.72 & & & & & & & & & \\
\hline \multirow[t]{2}{*}{ TFL } & 1 & 7 & 0.173 & 0.158 & .853 & & & & & & \\
\hline & 0.79 & & & & & & & & & & \\
\hline \multirow[t]{2}{*}{ ALT } & 6 & .587 & 0.139 & 0.126 & 0.59 & .766 & & & & & \\
\hline & 0.79 & 0.58 & & & 0.32 & 0.57 & & & & & \\
\hline CONS & 4 & 2 & 0.199 & 0.128 & 6 & 2 & .763 & & & & \\
\hline SPOR & 0.78 & 0.56 & & & 0.13 & & & & & & \\
\hline $\mathrm{T}$ & 8 & 8 & 0.163 & 0.105 & 1 & 0.14 & 0.171 & .754 & & & \\
\hline COUR & 0.78 & 0.55 & & & 0.12 & 0.08 & & & & & \\
\hline \multirow[t]{2}{*}{$\mathrm{T}$} & 4 & 1 & 0.136 & 0.154 & 7 & 3 & 0.179 & 0.438 & .742 & & \\
\hline & 0.78 & 0.63 & & & & 0.13 & & & & & \\
\hline \multirow[t]{2}{*}{ CIV } & 7 & 4 & 0.182 & 0.297 & 0.12 & 6 & 0.209 & 0.168 & 0.13 & .796 & \\
\hline & 0.81 & 0.63 & & -0.19 & 0.37 & 0.54 & & & & 0.33 & 0.79 \\
\hline \multirow[t]{2}{*}{ JP } & 6 & 9 & 0.156 & 2 & 7 & 1 & 0.624 & 0.321 & 0.272 & 4 & 9 \\
\hline & & & & & 3.05 & 3.58 & & & & 3.93 & 3.62 \\
\hline \multirow[t]{2}{*}{ Mean } & & & 3.29 & 3.507 & 5 & 8 & 3.401 & 2.6 & 4.271 & 5 & 6 \\
\hline & & & & & 0.63 & 0.87 & & & & 0.67 & 0.79 \\
\hline SD & & & 0.626 & 0.654 & 1 & 3 & 0.775 & 0.868 & 0.465 & 7 & 4 \\
\hline
\end{tabular}

4. Results

Hypothesis testing

4.1.1 Testing the Effect of Affective Commitment (AC) on Job Performance (JP)

In Table 3, the results in model 2 show that AC had significantly positive effect on JP holding other factors such as age, gender, position and educational background constant. This finding supports hypothesis 1 , which states that AC will positively influence JP of the employees. 


\section{Macrothink}

Table 3. The Effects of Affective Commitment (AC) on Job Performance (JP)

\begin{tabular}{lll}
\hline Variable & \multicolumn{2}{c}{ Job Performance } \\
\cline { 2 - 3 } Constant & Model 1 & Model 2 \\
\hline & $-0.582^{* * *}$ & $0.675^{* * *}$ \\
Gender & $0.241^{* * *}$ & -0.376 \\
& -0.058 & $0.102^{*}$ \\
Age & $-0.176^{* * *}$ & -0.057 \\
& -0.029 & $-0.156^{* * *}$ \\
& & -0.029 \\
Educational Background & -0.077 & -0.075 \\
& $0.125^{* * *}$ & -0.011 \\
MMDAs Type & -0.039 & -0.038 \\
& $-0.062^{* * *}$ & $-0.055^{* * *}$ \\
Location & -0.011 & -0.011 \\
& $0.124 * * *$ & $0.123^{* * *}$ \\
Position & -0.036 & -0.035 \\
Affective Commitment & & $0.331^{* * *}$ \\
F-test & & -0.058 \\
R-squared & $41.86^{* * *}$ & $42.55^{* * *}$ \\
Adj R-squ & 0.314 & 0.352 \\
Obs & 0.306 & 0.344 \\
\hline & 556 & 556 \\
\hline
\end{tabular}

$* * * * *$ indicate significant at $10 \%, 5 \%$ and $1 \%$ levels of significance.

\subsection{Testing the Effect of Affective Commitments (AC) on Organizational Citizenship Behaviour (OCB)}

The results in Table 4 show the effect of AC on OCB dimensions. Concerning altruism as the dependent variable, the results in model $1 \mathrm{~b}$ show that AC had significantly positive effect on altruism holding other factors constant. With reference to conscientiousness citizenship behaviour as the dependent variable, the results in models $2 \mathrm{~b}$ show that AC had significantly positive effect on conscientiousness suggesting that $\mathrm{AC}$ is an influencing factor with $\mathrm{OCB}$ framework controlling for other variables that affect OCB. Concerning sportsmanship as the dependent variable, the results in model $3 \mathrm{~b}$ show that $\mathrm{AC}$ had significantly positive effect on sportsmanship. Using courtesy and civic virtue as the dependent variables, the results in both model $4 \mathrm{~b}$ and model $5 \mathrm{~b}$ show that $\mathrm{AC}$ had significantly positive effect on courtesy and civic virtue. Generally, the results support hypothesis 2, which states that AC will positively, influence OCB. The results further show that among the five dimensions of OCB, AC has the strongest marginal effect on conscientious dimension of OCB but weakest with sportsmanship dimension. 


\section{Macrothink}

International Journal of Human Resource Studies

ISSN 2162-3058 2020, Vol. 10, No. 4

Table 4. The Effect of Affective Commitment (AC) on Organizational Citizenship Behaviour (OCB)

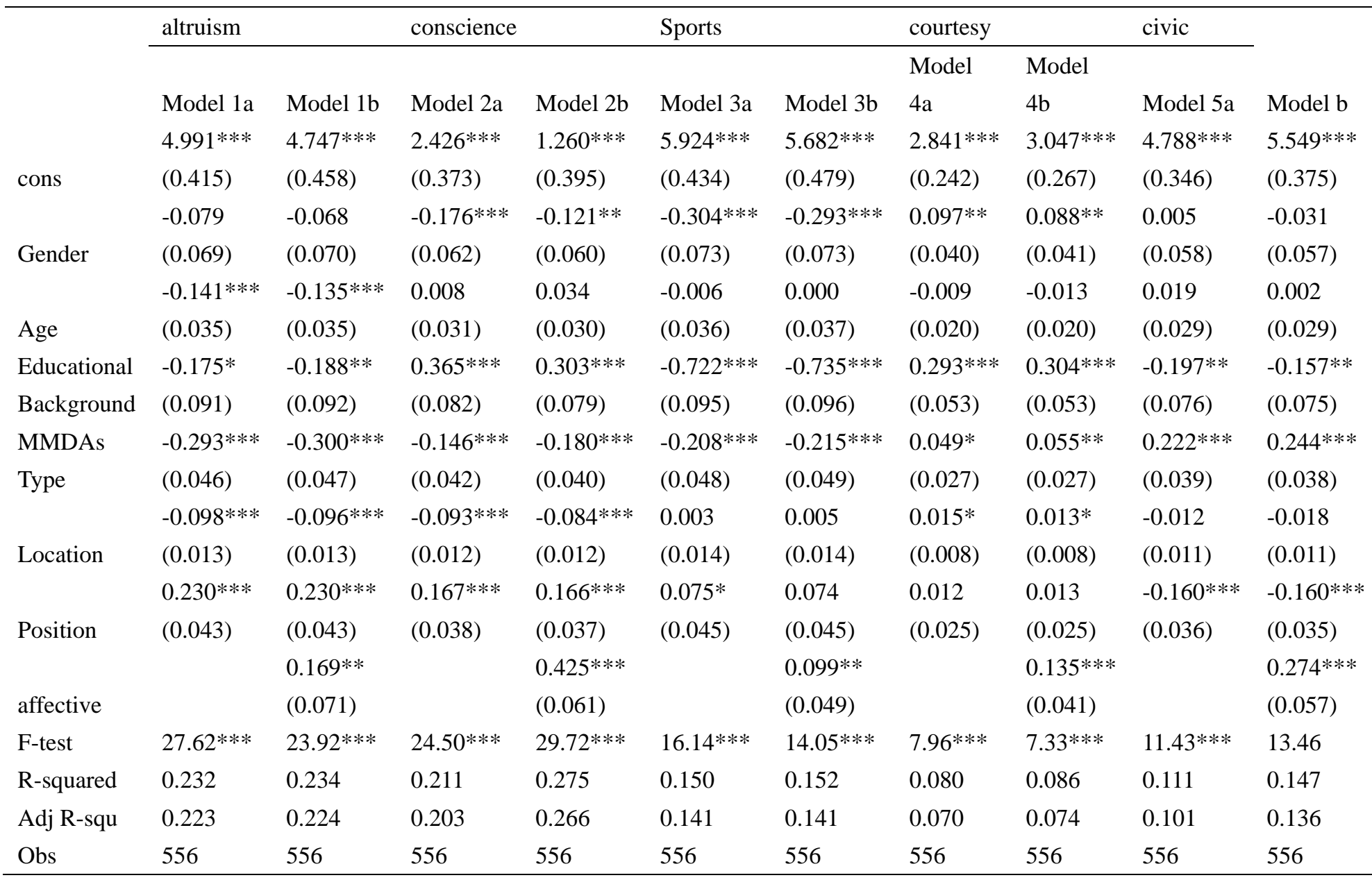

****,* means significant at 1\%,5\% and $10 \%$ significance levels.

\subsection{Testing the Effects of Organizational Citizenship Behaviour (OCB) on Job Performance $(J P)$}

The results in model 2 of Table 5 indicate that all the constructs of OCB had significantly positive effects on JP while controlling for other JP determinants such as age, gender, location and educational background of employees. Thus, the results support hypothesis 3, which states that OCB exert positive effects on JP of employees among the MMDAs in Ghana. However, the result in Table 5 show that courtesy dimension of OCB has the strongest marginal effects while civic virtue has the weakest marginal effects on JP. 


\section{Macrothink}

Table 5. The effect of organizational citizenship behaviour on job performance

\begin{tabular}{lll}
\hline & \multicolumn{2}{l}{ Job Performance } \\
\cline { 2 - 3 } & Model 1 & Model 2 \\
\cline { 2 - 3 } _cons & $\left(0.582^{* * *}\right.$ & $0.870^{* *}$ \\
& $0.241^{* * *}$ & $(0.335)$ \\
Gender & $(0.058)$ & $-0.072^{*}$ \\
& $-0.176^{* * *}$ & $(0.038)$ \\
Age & $(0.029)$ & $-0.138^{* * *}$ \\
Educational & $0.636^{* * *}$ & $(0.019)$ \\
Background & $(0.077)$ & $0.212^{* * *}$ \\
& $0.125^{* * *}$ & $(0.052)$ \\
MMDAs Type & $(0.039)$ & $0.118^{* * *}$ \\
& $-0.062^{* * *}$ & $(0.026)$ \\
Location & $(0.011)$ & $-0.013 *$ \\
Position & $0.124 * * *$ & $(0.008)$ \\
altruism & $(0.036)$ & -0.015 \\
& & $(0.024)$ \\
conscience & & $0.246^{* * *}$ \\
& & $(0.027)$ \\
sportsmanship & & $0.353^{* * *}$ \\
courtesy & & $(0.030)$ \\
Civic virtue & & $0.243^{* * *}$ \\
F-test & & $(0.024)$ \\
R-squared & & $0.403^{* * *}$ \\
Adj R-squ & & $(0.043)$ \\
Obs & & $0.225^{* * *}$ \\
\hline
\end{tabular}

$* * *, * * *$ means significant at $1 \%, 5 \%$ and $10 \%$ significance levels.

\subsection{Testing the Mediation Role of Organizational Citizenship Behaviour (OCB)}

Using altruism as a mediator variable, the results in model 3 of Table 6 show that the coefficient of altruism is significant and positive suggesting that altruism significantly and positively mediates the relationship between AC and JP. Similarly, the results in model 4 of Table 6 show that the coefficient of conscientiousness is significant and positive indicating conscientiousness significantly and positively meditates the relationship between AC and JP. Regarding sportsmanship as the mediating variable, the results in model 5 of Table 6 show that the coefficient of sportsmanship is significant and positive indicating sportsmanship significantly and positively mediates the relationship between AC and JP. Finally, the results in models 6 and 7 of Table 6 show that courtesy and civic virtue individually had significant and positive mediating effects in the relationship between AC and JP. In general, the results from models 3 to 7 support hypothesis 4 indicating that OCB constructs mediate the relationship between AC and JP. Considering the mediating effects of the OCB, courtesy had 
the strongest mediating effects while civic virtue had the weakest mediating effects in the relationship between AC and JP. The coefficient of AC is significant in all the models suggesting partial mediation of OCB in the relationship between AC and JP. In addition, the results in model 8 of Table 6 show that all the five OCB constructs (altruism, conscience, sportsmanship, courtesy and civic virtue) jointly mediate the relationship between AC and JP providing further support for hypothesis 4. However, in the joint mediating effects, sportsmanship is the strongest mediating variable.

Table 6. Mediating Effects of Organizational Citizenship Behaviour in the relationship between Affective Commitment and Job Performance

\begin{tabular}{|c|c|c|c|c|c|c|c|c|}
\hline & \multicolumn{8}{|c|}{ Job performance } \\
\hline & Model 1 & Model 2 & Model 3 & Model 4 & Model 5 & Model 6 & Model 7 & Model 8 \\
\hline & $1.582 * * *$ & $0.675 * * *$ & $-1.081 * * *$ & -0.006 & $2.375 * * *$ & $-1.207 * * *$ & $1.316^{* * *}$ & 0.375 \\
\hline \multirow[t]{2}{*}{ Constant } & $(0.350)$ & $(0.376)$ & $(0.367)$ & $(0.313)$ & $(0.390)$ & $(0.376)$ & $(0.442)$ & $(0.349)$ \\
\hline & $0.241 * * *$ & $0.102 *$ & 0.027 & 0.067 & $-0.086^{*}$ & -0.052 & -0.002 & \\
\hline \multirow[t]{2}{*}{ Gender } & $(0.058)$ & $(0.057)$ & $(0.051)$ & $(0.047)$ & $(0.054)$ & $(0.052)$ & $(0.057)$ & 0.037 \\
\hline & $-0.176^{* * *}$ & $-0.156^{* * *}$ & $-0.106^{* * *}$ & $-0.174 * * *$ & $-0.156^{* * *}$ & $-0.148 * * *$ & $-0.156 * * *$ & $-0.126 * * *$ \\
\hline Age & $(0.029)$ & $(0.029)$ & $(0.026)$ & $(0.024)$ & $(0.027)$ & $(0.026)$ & $(0.029)$ & $(0.019)$ \\
\hline Educational & $0.636 * * *$ & $0.588 * * *$ & $0.657 * * *$ & $0.424 * * *$ & $0.368 * * *$ & $0.400 * * *$ & $0.570 * * *$ & $0.200 * * *$ \\
\hline Background & $(0.077)$ & $(0.075)$ & $(0.067)$ & $(0.063)$ & $(0.073)$ & $(0.070)$ & $(0.075)$ & $(0.052)$ \\
\hline MMDAs & $0.125 * * *$ & -0.011 & $0.100 * * *$ & $0.086 * *$ & $-0.076 *$ & -0.046 & 0.017 & $0.097 * * *$ \\
\hline \multirow[t]{2}{*}{ Type } & $(0.039)$ & $(0.038)$ & $(0.035)$ & $(0.032)$ & $(0.036)$ & $(0.035)$ & $(0.039)$ & $(0.026)$ \\
\hline & $-0.062 * * *$ & $-0.055^{* * *}$ & $-0.020 *$ & -0.010 & $-0.054 * * *$ & $-0.063 * * *$ & $-0.057 * * *$ & -0.011 \\
\hline \multirow[t]{2}{*}{ Location } & $(0.011)$ & $(0.011)$ & $(0.010)$ & $(0.009)$ & $(0.010)$ & $(0.010)$ & $(0.011)$ & $(0.007)$ \\
\hline & $0.124 * * *$ & $0.123 * * *$ & 0.038 & 0.033 & $0.145 * * *$ & $0.115 * * *$ & $0.105^{* * *}$ & -0.008 \\
\hline \multirow[t]{2}{*}{ Position } & $(0.036)$ & $(0.035)$ & $(0.032)$ & $(0.029)$ & $(0.033)$ & $(0.032)$ & $(0.036)$ & $(0.023)$ \\
\hline & & $0.331 * * *$ & $0.298 * * *$ & $0.101 * *$ & $0.357 * * *$ & $0.377 * * *$ & $0.299 * * *$ & $0.258 * * *$ \\
\hline \multirow[t]{2}{*}{ affective } & & $(0.058)$ & $(0.052)$ & $(0.050)$ & $(0.054)$ & $(0.052)$ & $(0.059)$ & $(0.027)$ \\
\hline & & & $0.370 * * *$ & & & & & $0.316 * * *$ \\
\hline \multirow[t]{2}{*}{ Altruism } & & & $(0.031)$ & & & & & $(0.031)$ \\
\hline & & & & $0.540 * * *$ & & & & $0.249 * * *$ \\
\hline \multirow[t]{2}{*}{ conscience } & & & & $(0.033)$ & & & & $(0.024)$ \\
\hline & & & & & $0.299 * * *$ & & & $0.410 * * *$ \\
\hline \multirow[t]{2}{*}{ sportsmanship } & & & & & $(0.031)$ & & & $(0.043)$ \\
\hline & & & & & & $0.617 * * *$ & & $0.208 * * *$ \\
\hline \multirow[t]{2}{*}{ Courtesy } & & & & & & $(0.054)$ & & $(0.028)$ \\
\hline & & & & & & & $0.115^{* * *}$ & $0.168 * * *$ \\
\hline Civic virtue & & & & & & & $(0.043)$ & $(0.039)$ \\
\hline F-test & $41.86 * * *$ & $42.55 * * *$ & $64.07 * * *$ & $87.54 * * *$ & $55.12 * * *$ & $62.23 * * *$ & $38.58 * * *$ & 130.5 \\
\hline R-squared & 0.314 & 0.352 & 0.484 & 0.561 & 0.446 & 0.477 & 0.461 & 0.743 \\
\hline Adj R-squ & 0.306 & 0.344 & 0.476 & 0.555 & 0.438 & 0.469 & 0.451 & 0.737 \\
\hline Obs & 556 & 556 & 556 & 556 & 556 & 556 & 556 & 556 \\
\hline
\end{tabular}

$* * *, * *, *$ means significant at $1 \%, 5 \%$ and $10 \%$ significance levels. 


\section{Macrothink}

International Journal of Human Resource Studies

ISSN 2162-3058 2020, Vol. 10, No. 4

4.5 Testing the Moderating Role of Leadership Styles (transformational TFL and Transactional TSL)

In models 3 and 4, the results show that the coefficient of the interaction terms of leadership styles (TFL and TSL) and AC is positive and significant suggesting leadership styles strengthen the relationship between AC and JP. However, the coefficients of the interaction terms (see model 3) of TSL and AC is stronger than the coefficient of the interaction terms (see model 4) of TFL and AC indicating that TSL has stronger moderating influence than TSL. The findings partly support hypothesis 5 that states leadership styles have moderating influence on AC and JP relationships but rather rejects TFL as having stronger moderating effect.

Table 7. Moderating role of leadership styles Transformational and Transactional (TFL and TSL)

\begin{tabular}{|c|c|c|c|c|}
\hline & \multicolumn{4}{|c|}{ Job Performance } \\
\hline & Model 1 & Model 2 & Model 3 & Model 4 \\
\hline & $1.582 * * *$ & $1.641 * * *$ & $2.625 * * *$ & $1.838^{*}$ \\
\hline \multirow[t]{2}{*}{ Constant } & $(0.350)$ & $(0.943)$ & $(1.235)$ & $(0.949)$ \\
\hline & $0.241 * * *$ & -0.004 & 0.048 & -0.001 \\
\hline \multirow[t]{2}{*}{ Gender } & $(0.058)$ & $(0.057)$ & $(0.056)$ & $(0.057)$ \\
\hline & $-0.176^{* * *}$ & $-0.140 * * *$ & $-0.104 * * *$ & $-0.150 * * *$ \\
\hline \multirow[t]{2}{*}{ Age } & $(0.029)$ & $(0.029)$ & $(0.029)$ & $(0.029)$ \\
\hline & $0.636 * * *$ & $0.579 * * *$ & $0.611 * * *$ & $0.589 * * *$ \\
\hline \multirow[t]{2}{*}{ Educational Background } & $(0.077)$ & $(0.075)$ & $(0.073)$ & $(0.075)$ \\
\hline & $0.125 * * *$ & 0.001 & 0.003 & -0.007 \\
\hline \multirow[t]{2}{*}{ MMDAs Type } & $(0.039)$ & $(0.038)$ & $(0.037)$ & $(0.038)$ \\
\hline & $-0.062 * * *$ & $-0.056 * * *$ & $-0.033 * * *$ & $-0.057 * * *$ \\
\hline \multirow[t]{2}{*}{ Location } & $(0.011)$ & $(0.011)$ & $(0.011)$ & $(0.011)$ \\
\hline & $0.124 * * *$ & $0.113 * * *$ & $0.096 * * *$ & $0.117 * * *$ \\
\hline \multirow{3}{*}{$\begin{array}{l}\text { Position } \\
\text { Affective } \\
\text { (AC) }\end{array}$} & $(0.036)$ & $(0.035)$ & $(0.034)$ & $(0.035)$ \\
\hline & & 0.170 & $1.038 * * *$ & $0.475^{* *}$ \\
\hline & & $(0.286)$ & $(0.390)$ & $(0.209)$ \\
\hline \multirow{4}{*}{$\begin{array}{l}\text { Transactional Leadership } \\
\text { Style (TSL) } \\
\text { Transformational } \\
\text { Leadership Style (TFL) }\end{array}$} & & & $0.931 * * *$ & \\
\hline & & & $(0.341)$ & \\
\hline & & & & $0.509 * * *$ \\
\hline & & & & $(0.164)$ \\
\hline \multirow{2}{*}{ AC X TSL } & & & $\begin{array}{l}0.316^{* * * *} \\
(0.113)\end{array}$ & \\
\hline & & & & $0.144 * *$ \\
\hline AC X TFL & & & & $(0.065)$ \\
\hline F-test & $41.86^{* * *}$ & $34.9 * * *$ & $40.3^{* * *}$ & $33.66 * * *$ \\
\hline R-squared & 0.314 & 0.565 & 0.599 & 0.557 \\
\hline Adj R-squared & 0.306 & 0.555 & 0.589 & 0.546 \\
\hline Observations & 556 & 556 & 556 & 556 \\
\hline
\end{tabular}

***,*,* means significant at 1\%, 5\% and $10 \%$ significance levels. 
Moderating Graphs

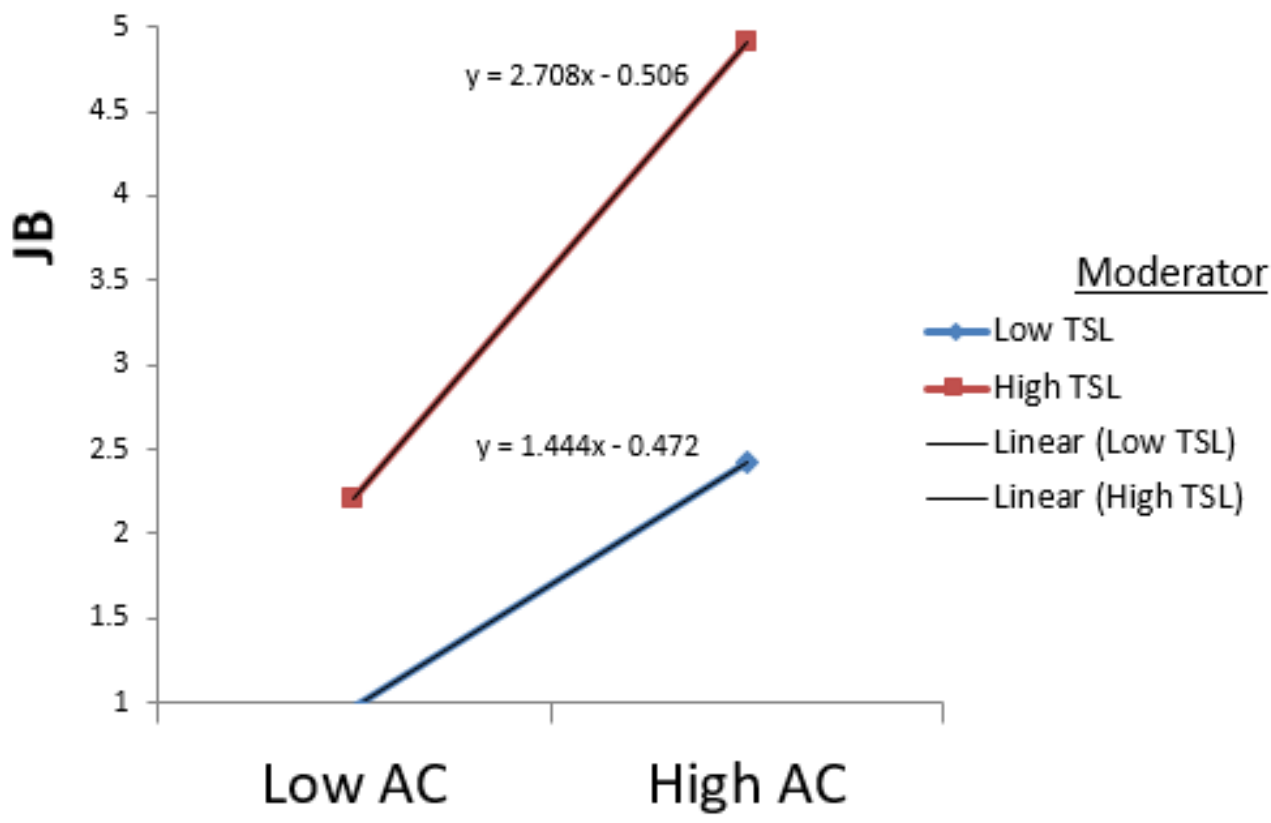

Fig. 1.2 The moderation role of TSL on the relationship between AC and JP

TSL strengthens the positive relationship between AC and JP.

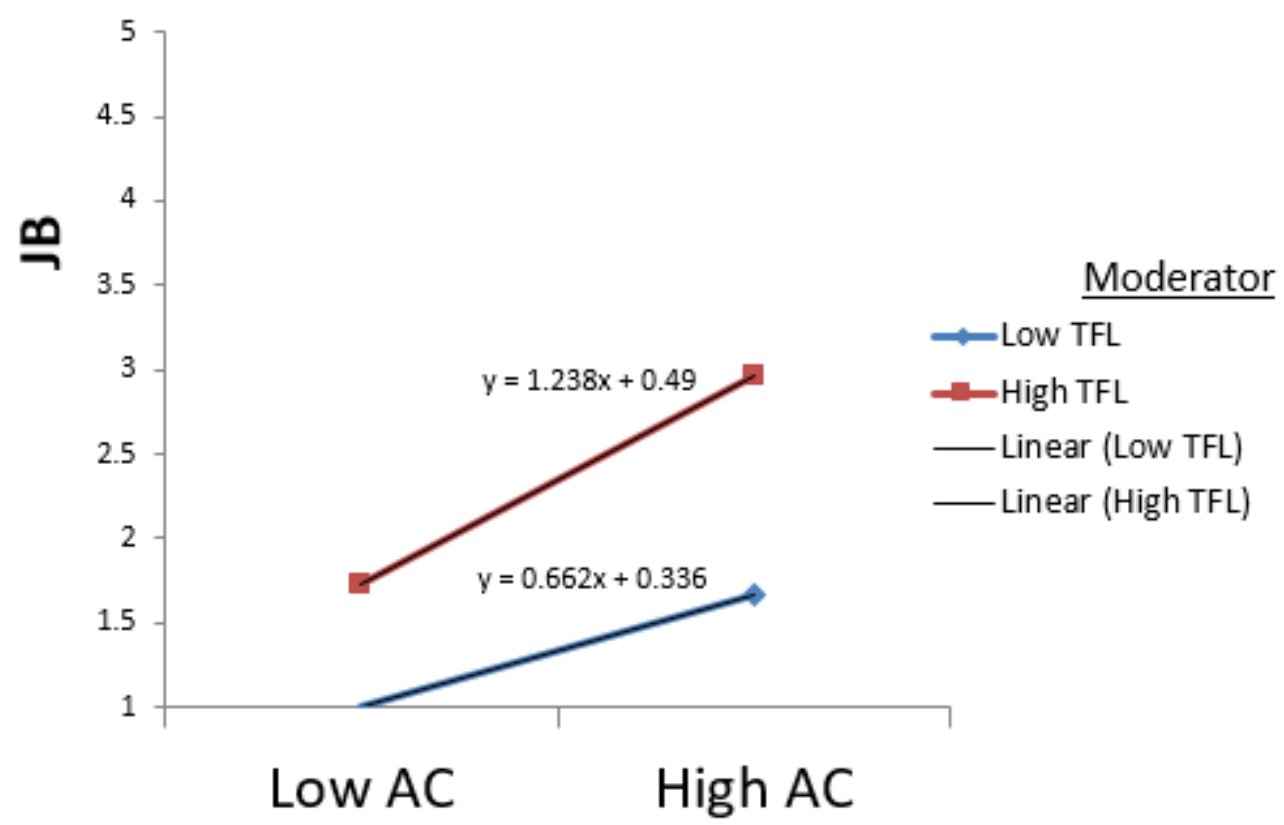

Fig. 1.3 The moderation role of TFL on the relationship between AC and JP

\section{Discussion}

This paper had three main objectives; (a) to identify the influence that affective commitment will exert on the job performance of employees; (b) to examine whether or not OCB acts as a 
mediator in the relationship between affective organizational commitment and employee job performance; and (c) to explore the moderating effects of leadership styles (transformational and transactional) on the relationship between affective commitment and job performance. The outcome of our study is discussed below:

\subsection{Affective Commitment (AC) and Job Performance (JP)}

Our findings clearly show that AC significantly predict JP. These findings support earlier research outcomes that affective commitment positively affect job performance (Riketta, 2002; Meyer et al., 2013; Hafiz, 2017; Sungu, Weng\& Xu 2019). These scholars asserted that organizational commitment in general positively improves JP. According to Demirel and Goc (2013) workers with higher level of commitment are industrious, efficient in production, compatible, loyal, responsive which comes as a competitive advantage to their organization.

This result also suggests that within the MMDAs in Ghana, some employees have developed an emotional attachment to the organization such that they are dedicated to the objective of delivering quality services to the people. According to Meyer \& Allan (1991) employees with AC have an emotional commitment to, affiliation with, and involvement with the organization. They argue further that workers with a good AC tend to work for the organization as they would prefer to do so. According to Azeem (2010) and Al Zeifeti\& Mohamad (2017) committed employees make a lot of effort to ensure that their organization achieves its ultimate objective. Consistent with this line of thinking, we argue that MMDAs in Ghana need employees who believe deeply in the organizational principles and objectives and are willing to make a great deal of effort on behalf of the organization. These employees must have the inner feeling to be part of the success story of the MMDAs as this intrinsic motivation can encourage employees to work better.

The outcome of this study also gives credence to the assertion that an essential ingredient in boosting JP is AC. That performance depends on interpersonal behaviours in a working environment which occur as a result of high organizational commitment.

\subsection{Mediating Role of Organizational Citizenship Behaviour (OCB)}

It is hypothesized in this study that OCB will mediate the relationship between AC and JP. For this purpose, we first seek to establish the relationship between AC and OCB. Secondly the correlation between OCB and JP since we have already established the positive relationship existing between $\mathrm{AC}$ and JP. Consistent with empirical literature, our findings revealed that $\mathrm{AC}$ had significant positive effect on $\mathrm{OCB}$. Consequently, our findings support the assertion of earlier researchers that AC positively affects OCB (Organ and Ryan; 1995; LePine et al. 2002; Zehir et al., 2012; Grego-Planer 2019). Our results indicate that some employees of the MMDAs go beyond the normal work duties voluntarily to ensure that the organization succeeds since the strongest effect of AC was on the conscientiousness dimension of OCB. According to Zehir, Muceldili, \&Zehir, (2012) workers with high AC are emotionally committed to the organisation, and are able to participate in organizational activities voluntarily. Our findings corroborate the argument made by these scholars.

The outcome of the study further shows that OCB significantly predicts JP since all the 
dimensions of OCB had effect on JP. This corroborate the results of previous research works that established that OCB improves JP by enhancing employees ' and management ability to plan, solve problems and institute good policies and programmes towards the achievement of organizational goals (MacKenzie, Podsakoff and Fetter; 1991; Hui, Lee and Rousseau 2004; Al-Mahasneh 2015; Basu et al., 2017). This brings to light the importance of citizenship behaviour in the MMDAs for two main reasons: (a) achieving overall organizational goal of providing quality social services in the area of health, education, water, sanitation etc. and (b) hire and retain quality human resources. George and Bettenhausen (1990) claim that institutions that promote good attitudes akin to citizenship behaviours are more desirable organizations to work with and are able to recruit and retain the best employees.

The outcome of the mediation analysis showed that OCB mediates the relationship between AC and JP since all the dimensions of OCB mediated the relationship between AC and JP. This provides further empirical validation to the assertion that OCB mediates the relationship between organizational commitment and job performance (Rahman \& Karan, 2011). This result implies that, while organizational commitment is linked to JP, the relationship is even made stronger through OCB. It further suggests that workers who are high in AC are likely to demonstrate OCB which has the tendency to improve their JP. This interpretation is premised on the assumption that organizational commitment is an antecedent of OCB and the logical conclusion that JP is an outcome variable. In our study, the positive effect of AC on OCB and that of OCB on JP is largely supported.

\section{Moderating effect of leadership Styles (Transformational TFL and Transactional TSL)}

From the findings of our study, leadership styles TFL and TSL have significant moderating effect on the relationship between AC and employee JP such that the relationship is further strengthened. Our result in this instance supports the assertion that TFL moderates and strengthens the relationship between AC and JP (Sungu, Weng\& Xu, 2019). However, unlike Sungu, Weng\& Xu (2019) we found TSL as having the strongest moderating effect on AC and JP relationship. The outcome of our study suggest that contrary to the overwhelming research findings by scholars that TFL is the most effective leadership style in achieving employee JP (Bass, 1985; MacKenzie et al., 2001; Walumbwa et al., 2004; Vigoda-Godat, 2007; Emery \& Barker, 2007; Hoxha, 2019), our study highlights TSL as the most effective leadership style in achieving maximum employee commitment and performance. From the findings one can infer that workers within the MMDAs in Ghana prefer working with leaders (MMDCEs or mayors) who possess TSL traits than TFL since TSL was very effective in enhancing employees' AC and JP. According to Suryanarayana (2011) leaders who exhibit TSL traits make significant contribution to workers commitment and performance. An indication that transactional leaders are very effective in persuading their staff or subordinates to perform better.

Additionally, TSL was most effective in strengthening AC and JP relationship partly due to the fact that Ghana is a developing country with her economy going through major transformation as a result many employees of the MMDAs may be pursuing materialistic and tangible rewards. According to Bass (1985) and Awamleh\& Gardner (1999)TSL represent 
reciprocal arrangement of exchange in which the leader meets the needs of subordinates in return for performance that meets the leader's basic standards. In other words, the leader and subordinates negotiate a deal on what rewards the subordinates will get for a specific performance. Once the contracted performance level is met, the leader offers rewards, incentives or recognition (Judge \& Piccolo, 2004; Si \& Wei, 2012; Lee\& Wei, 2017).

\section{Conclusion}

The outcome of our study clearly indicates that organizational commitment positively influences employee job performance. This brings to the foe the need for leaders to motivate their staff since committed workforce mostly share the organizational vision and dedicate their time and energies towards the achievement of this organizational vision. Also, it is evident from our research findings that affective commitment positively predicts OCB and that OCB positively influences employee job performance. Further, we have demonstrated that OCB mediates the relationship between affective commitment and employee job performance. The logical conclusion is that committed employees are normally willing and ready to go beyond their normal line of duty and engage themselves in discretionary activities which benefit their organization. This obviously will lead to improved job performance which helps in achieving the overall organizational goal. Furthermore, both transformational and transactional leadership behaviours moderated and strengthened the positive relationship between affective commitment and employee job performance but contrary to our prediction transactional leadership was most effective in strengthening this relationship than transformational leadership. The outcome of our study suggests that Metropolitan, Municipal and District Chief Executives (MMDCEs/Mayors) should provide effective leadership that creates conducive organizational environment with the necessary incentives and perks that motivates and encourages the employees to give off their best towards the MMDAs goal of providing quality social services to their constituents.

\section{The Implications of the Study}

Our study findings have implications both for theory as well as practice. With regard to theory, our results provide further empirical validation for the assertion that an essential factor in improving JP is AC. Aside the contribution of our study to commitment and JP relationship, our findings provides further support and empirical relevance in developing a theory on OCB. The outcome of our mediation analysis is in tandem with the assertion that once workers perceive that there is fairness in the management of their organization, they are willing to improve their OCB and job performance (Organ, 1988). We have shown in this regard that within the Ghanaian local government context OCB plays a mediating role between AC and JP which is a novel contribution. We thus validate the theoretical argument that organizational commitment is an antecedent of OCB and the logical conclusion that JP is an outcome variable.

Additionally, we have demonstrated the circumstances under which AC is more positively related to JP. From our study, though AC positively relates with JP the relationship varies with the levels of the leaders (MMDCEs /Mayor's) leadership style. The results from the study give credence to the argument that the relationship between organizational commitment 
and JP is dependent on other foci of commitment and contextual factors (Meyer, Becker, \&Vandenberghe, 2004). In particular, we have shown that the relationship between AC and JP can be moderated by LDS (TFL and TSL) which is innovative contribution to theoretical and empirical literature.

Furthermore, our study also contributes significantly to literature on leadership. We realized that within the local government context in Ghana, organizational commitment is more closely or strongly related to JP when leaders (MMDCEs/mayors) TSL rather than TFL is high. TFL and TSL leadership styles inculcate into subordinates' specific traits that encourages and motivates followers improve performance (Bass \& Avolio, 1985; Bass \& Riggio, 2006; Lee \& Wei, 2017). Earlier research findings indicate that TFL more closely or strongly relates to JP than TSL (Bass, 1985; MacKenzie et al., 2001; Walumbwa et al., 2004; Vigoda-Godat, 2007; Emery \& Barker, 2007; Hoxha, 2019). However, our results showed the opposite. Employees in the MMDAs prefer a leader who will give them tangible or material rewards in exchange for their performance. This is unique and innovative theoretical contribution because by identifying TSL as the most effective leadership style in achieving high commitment and JP in an African context, we add socio-cultural perspective to this relationship as most previous studies that identified TFL as the most effective leadership behaviour in achieving employee commitment and performance were done outside the Ghanaian context.

Pertaining to practice, we have shown that AC is positively related to JP. This brings to light the significance of recruiting and training dedicated workers in an organization. According to Tett \& Meyer (1993) dedicated and committed employees are not only less likely to leave an organization but also more likely to show high JP. In this regard, the Ministry of Local Government and Rural Development (MLGRD) as well as the Local Government Service (LGS) must pay particular attention to the employees' curriculum vitae and employment history during recruitment of staff into the MMDAs. This can give an important indication or trends to assist in decision making. Priority can therefore be given to employees who spent more years in their former organizations as compared to those with very "nomadic" nature of employment history.

Secondly, considering the role of OCB in achieving high commitment and performance, MMDCEs as leaders of the MMDAs should create an organizational environment that is cozy, family like and encourages consensus building where employee's welfare issues is a priority. This has the capacity of motivating employees to develop an emotional attachment towards the MMDA and may be willing to go beyond their normal line of duty. George and Bettenhausen (1990) argue that organizations that foster positive habits akin to citizenship behaviour are more desirable places to work and are able to recruit and retain the best employees.

Thirdly, we found that TFL and TSL styles strengthen the effect of AC on JP. We recommend that the MLGRD and LGS in collaboration with the Institute for Local Government Service (ILGS) organize capacity training workshop which focuses on TFL and TSL leadership traits for MMDCEs. This is because the quality of exchange and interaction between leaders and 
followers is essential in order to achieve the commitment of employees (Judge \&Piccolo, 2004). Trust building, respecting and caring should be important aspects of the successful management of human resources in Ghanaian organizations.

\section{Limitations and Future Research Prospects}

In our work, we have contributed and enriched empirical research on AC and JP relationship. That notwithstanding, there are shortcoming, the data for the study was collected from only local government employees from the MMDAs in the western region of Ghana, which may inhabit the generalizability of the research findings. Secondly, we only used AC in our model so future research works can investigate the effect of other dimensions of commitment (continuance or normative) on and JP. Also, we did not factor the differences among the MMDAs ie Metropolitan, Municipal and District, however we controlled for this differentials in the present work to minimize its impact on the result. Therefore, in subsequent studies, researchers need to widen the scope to include data from other organizations, such as private companies and other non-profit organizations, and incorporate comparative analysis of the data obtained from these different institutions.

\section{Acknowledgments}

We wish to express our heartfelt appreciation to Professor Yongyue Zhu of School of Management, Jiangsu University, P.R. China for painstakingly going through this manuscript and his insightful contributions. We are also grateful to Mr. Isaac Kwamina Afful (CEO, Lower Pra Rural Bank Ltd and Mr. Samuel Kwame Borlu (Western Global Technologies Ltd) for their support. Finally, to Mr Frank Kwesi Yeboah and $\mathrm{Mr}$ Kwame Tawiah of (Sekondi/Takoradi Metropolitan Assembly) for their contributions during data collection

\section{References}

Abu Tayeh, B. (2012). The Effect of Organizational Justice on Organizational Citizenship Behaviour in Government Ministries Centers in Jordan. Islamic University Economic and Administrative Studies Journal, 20, 145-186.

Adams, S. (2012). Decentralisation: To Elect or Appoint the District Chief Executive. Journal of Local Government Studies, 4(1), 105-123.

Ahwoi, K. (2010). Local Government and Decentralisation in Ghana. Unimax Macmillan, Accra.

Al Zefeiti, S. M. B., \& Mohamad, N. A. (2017). The Influence of organizational commitment on Omani public employees' work performance. International Review of Management and Marketing, 7(2), 151-160.

Al-Mahasneh, M. A. (2015). The impact of organizational citizenship behaviour on job performance at greater amman municipality. European Journal of Business and Management, $7(36), 108-118$.

Avolio, B. J., \& Bass, B. M. (1991). The full-range of leadership development. Binghamton. NY. Center for Leadership Studies. 
Awamleh, R., \& Gardner, W. L. (1999). Perceptions of leader charisma and effectiveness: The effects of vision content, delivery, and organizational performance. The leadership quarterly, 10(3), 345-373.

Azeem, S. M. (2010). Job satisfaction and organizational commitment among employees in the Sultanate of Oman. Psychology, 1(4), 295-300.

Bandula, P. M. K. U., \& Jayatilake, L. V. (2016). Impact of employee commitment on job performance: Based on leasing companies in Sri Lanka. International Journal of Arts and Commerce, 5(8), 8-22.

Barsulai, S. C., Makopondo, R. O., \&Fwaya, E. V. (2019). The Effect of Organizational Citizenship Behaviour on Employee Productivity in Star Rated Hotels in Kenya. European Journal of Hospitality and Tourism Research, 7(1), 1-8.

Bass, B. M. (1999). Two decades of research and development in transformational leadership. European journal of work and organizational psychology, 8(1), 9-32.

Bass, B. M., \&Riggio, R. E. (2006). Transformational leadership (2nd ed.). Mahwah, NJ: Erlbaum.

Bass, B. M., \& Avolio, B. J. (2000). MLQ Multifactor Leadership Questionnaire. Redwood City, CA: Mind Garden.

Bass, B. M. (1985). Leadership and Performance beyond Expectations, Free Press, New York, NY.

Bass, B. M., \& Avolio, B. J. (1993), "Transformational leadership theory: a response to critiques", in Chemmers, M.M. and Ammons, R. (Eds), Leadership and Research: Perspectives and Direction, California Academic Press, Los Angeles, CA, pp. 49-80.

Basu, E., Pradhan, R. K., \&Tewari, H. R. (2017). Impact of organizational citizenship behaviour on job performance in Indian healthcare industries: The mediating role of social capital. International Journal of Productivity and Performance Management, 66(6), 780-796.

Benjamin, A. (2012). The influence of affective commitment on citizenship behaviour and intention to quit among commercial banks' employees in Nigeria. Journal of Management and Sustainability, 2(2), 54-68.

Blau, P. M. (1964). Exchange and power in social life. New York: Wiley.

Burns, J. M. (1978). Leadership, Harper \& Row, New York, NY.

Cohen, A., \& Keren, D. (2008). Individual values and social exchange variables: Examining their relationship to and mutual effect on in-role performance and organizational citizenship behaviour. Group \& Organization Management, 33(4), 425-452.

Cohen, A., Ben-Tura, E., \&Vashdi, D. R. (2012). The relationship between social exchange variables, $\mathrm{OCB}$, and performance: What happens when you consider group characteristics? Personnel Review, 41(6), 705-731. 


\section{Macrothink}

International Journal of Human Resource Studies

ISSN 2162-3058

2020, Vol. 10, No. 4

Demirel, Y., \&Goc, K. (2013). The impact of organizational commitment on knowledge sharing. In 1st Annual International Interdisciplinary Conference (pp. 954-963).

Emery, C. R., \& Barker, K. J. (2007). The effect of transactional and transformational leadership styles on the organizational commitment and job satisfaction of customer contact personnel. Journal of organizational culture, communications and conflict, 11(1), 77.

Flynn, F. J., \& Schaumberg, R. L. (2012). When feeling bad leads to feeling good: Guilt-proneness and affective organizational commitment. Journal of Applied Psychology, 97(1), 124.

Fornell, C., \& Larcker, D. F. (1981). Structural equation models with unobservable variables and measurement error: Algebra and statistics. Journal of Marketing Research, 18(3), 382-388.

Gaskin, J., \& Lim, J. (2016). Model fit measures. Gaskination 'sStatWiki, 1-55.

George, J. M., \& Bettenhausen, K. (1990). Understanding prosocial behaviour, sales performance, and turnover: A group-level analysis in a service context. Journal of applied psychology, 75(6), 698.

Geyery, A. L., \&Steyrer, J. M. (1998). Transformational leadership and objective performance in banks. Applied Psychology, 47(3), 397-420.

Grego-Planer, D. (2019). The relationship between organizational commitment and organizational citizenship behaviours in the public and private sectors. Sustainability, 11(22), 6395.

Grojean, M. W., Resick, C. J., Dickson, M. W., \& Smith, D. B. (2004). Leaders, values, and organizational climate: Examining leadership strategies for establishing an organizational climate regarding ethics. Journal of business ethics, 55(3), 223-241.

Hafiz, A. Z. (2017). Relationship between organizational commitment and employee's performance evidence from banking sector of Lahore. Arabian Journal of Business and Management Review, 7(2), 1-7.

Hendri, N. (2019). The impact of organizational commitment on job performance. International Journal of Economics \& Business Administration, 7(2), 189-206.

House, R. J. (1995). Leadership in the twenty-first century: A speculative inquiry. Reginald H. Jones Center, Wharton School, University of Pennsylvania.

Hoxha, A. (2019) Transformational and transactional leadership styles on employee performance International Journal of Humanities and Social Science Invention, 8(11), 46-58

Hui, C., Lee, C., \& Rousseau, D. M. (2004). Psychological contract and organizational citizenship behaviour in China: Investigating generalizability and instrumentality. Journal of Applied Psychology, 89(2), 311.

Irefin, P., \& Mechanic, M. A. (2014). Effect of employee commitment on organizational 
performance in Coca Cola Nigeria Limited Maiduguri, Borno state. Journal of Humanities and Social Science, 19(3), 33-41.

Jamal, M. (2011). Job stress, job performance and organizational commitment in a multinational company: An empirical study in two countries. International Journal of Business and Social Science, 2(20).

Judge, T. A., \& Piccolo, R. F. (2004). Transformational and transactional leadership: a meta-analytic test of their relative validity. Journal of applied psychology, 89(5), 755.

Kehoe, R. R., \& Wright, P. M. (2013). The impact of high-performance human resource practices on employees' attitudes and behaviours. Journal of management, 39(2), 366-391.

Khan, M. R., Ziauddin, J. F. A., \&Ramay, M. I. (2010). The impacts of organizational commitment on employee job performance. European Journal of Social Sciences, 15(3), 292-298.

Klein, H. J., Cooper, J. T., Molloy, J. C., \& Swanson, J. A. (2014). The assessment of commitment: Advantages of a unidimensional, target free approach. Journal of Applied Psychology, 99(2), 222-238. https ://doi.org/10.1037/a0034751

Klein, H. J., Cooper, J. T., Molloy, J. C., \& Swanson, J. A. (2014). The assessment of commitment: Advantages of a unidimensional, target-free approach. Journal of Applied Psychology, 99(2), 222.

Klein, H. J., Molloy, J. C., \&Brinsfield, C. T. (2012). Reconceptualizing workplace commitment to redress a stretched construct: Revisiting assumptions and removing confounds. Academy of management review, 37(1), 130-151.

Landrum, N. E., Howell, J. P., \& Paris, L. (2000). Leadership for strategic change. Leadership \& Organization Development Journal, 21(3), 150-157.

Lara, P. Z. M. D., \& Rodriguez, T. F. E. (2007). Organizational anomie as moderator of the relationship between an unfavorable attitudinal environment and citizenship behaviour (OCB): An empirical study among university administration and services personnel. Personnel Review, 36(6), 843-866.

Lee, J., \& Wei, F. (2008). Uncover the black-box of leadership effectiveness: Leader-member exchange as the mediator. Frontiers of Business Research in China, 2(2), 240.

Lee, J., \& Wei, F. (2017). The moderating effect of leadership on perceived organizational justice and affective commitment: a study in China. The International Journal of Human Resource Management, 28(5), 679-702.

LePine, J. A., Erez, A., \& Johnson, D. E. (2002). The nature and dimensionality of organizational citizenship behaviour: a critical review and meta-analysis. Journal of applied psychology, 87(1), 52 .

MacKenzie, S. B., Podsakoff, P. M., \& Fetter, R. (1991). Organizational citizenship behaviour and objective productivity as determinants of managerial evaluations of 
salespersons' performance. Organizational behaviour and human decision processes, 50(1), 123-150.

MacKenzie, S. B., Podsakoff, P. M., \& Rich, G. A. (2001). Transformational and transactional leadership and salesperson performance. Journal of the academy of Marketing Science, 29(2), 115.

Mallick, E., Pradhan, R. K., Tewari, H. R., \& Jena, L. K. (2014). Organizational citizenship behaviour, job performance and HR practices: A relational perspective. Management and Labour Studies, 39(4), 449-460.

Mathieu, J. E., \& Zajac, D. M. (1990). A review and meta-analysis of the antecedents, correlates, and consequences of organizational commitment. Psychological bulletin, 108(2), 171.

Meyer, J. P., \& Allen, N. J. (1991). A three-component conceptualization of organizational commitment. Human resource management review, 1(1), 61-89.

Meyer, J. P., \& Allen, N. J. (1997). Commitment in the workplace: Theory, research, and application. Sage.

Meyer, J. P., Allen, N. J., \& Smith, C. A. (1993). Commitment to organizations and occupations: Extension and test of a three-component conceptualization. Journal of applied psychology, 78(4), 538.

Meyer, J. P., Becker, T. E., \&Vandenberghe, C. (2004). Employee commitment and motivation: a conceptual analysis and integrative model. Journal of applied psychology, 89(6), 991.

Meyer, J. P., Kam, C., Goldenberg, I., \&Bremner, N. L. (2013). Organizational commitment in the military: Application of a profile approach. Military Psychology, 25(4), 381-401.

Mueller, K., Hattrup, K., Spiess, S. O., \& Lin-Hi, N. (2012). The effects of corporate social responsibility on employees' affective commitment: A cross-cultural investigation. Journal of applied psychology, 97(6), 1186.

Nasir, R., Mohammadi, M. S., Wan Shahrazad, W. S., Fatimah, O., Khairudin, R., \& Halim, F. (2011). Relationship between organizational citizenship behaviour and task performance. The social sciences, 6(4), 307-312.

Organ, D. W. (1988). Organizational citizenship behaviour: The good soldier syndrome. Lexington, KY: Lexington Books.

Organ, D. W., \& Ryan, K. (1995). A meta-analytic review of attitudinal and dispositional predictors of organizational citizenship behaviour. Personnel Psychology, 48(4), 775-802.

Organ, D. W., Podsakoff, P. M., \& MacKenzie, S. B. (2006), Organizational Citizenship Behaviour: Its Nature, Antecedents, and Consequences, Sage, Thousand Oaks, CA.

Parry, K.W. (2003) Leadership, culture and performance: the case of the New Zealand public 
sector. Journal of Change Management, 3(4), 376-399.

Pillai, R., Schriesheim, C. A., \& Williams, E. S. (1999). Fairness perceptions and trust as mediators for transformational and transactional leadership: A two-sample study. Journal of management, 25(6), 897-933.

Podsakoff, P. M., MacKenzie, S. B., Moorman, R. H., \& Fetter, R. (1990). Transformational leader behaviours and their effects on followers' trust in leader, satisfaction, and organizational citizenship behaviours. The leadership quarterly, 1(2), 107-142.

Podsakoff, P. M., MacKenzie, S. B., Paine, J. B., \&Bachrach, D. G. (2000). Organizational citizenship behaviours: A critical review of the theoretical and empirical literature and suggestions for future research. Journal of management, 26(3), 513-563.

Podsakoff, P. M., Todor, W. D., Grover, R. A., \& Huber, V. L. (1984). Situational moderators of leader reward and punishment behaviours: Fact or fiction? Organizational behaviour and human performance, 34(1), 21-63.

Podsakoff, P. M., Todor, W. M., \&Skov, R. (1982). Effects of leader contingent and noncontingent reward and punishment behaviours on subordinate performance and satisfaction. Academy of management journal, 25(4), 810-821.

Rahman, M. S., \& Karan, R. (2011) Relationship between organizational commitment and job performance and the mediating role of organizational citizenship behaviour.The Chittagong University Journal of Business Administration, 26(4), 325-350.

Reader, T. W., Mearns, K., Lopes, C., \&Kuha, J. (2017). Organizational support for the workforce and employee safety citizenship behaviours: A social exchange relationship. Human relations, 70(3), 362-385.

Riketta, M. (2002). Attitudinal organizational commitment and job performance: a metaanalysis. Journal of Organizational Behaviour: The International Journal of Industrial, Occupational and Organizational Psychology and Behaviour, 23(3), 257-266.

Robbins, S. \& Judge, T. (2009). Organizational Behaviour (13th ed). New Delhi: Prentice Hall of India.

Salehi, M., \&Gholtash, A. (2011). The relationship between job satisfaction, job burnout and organizational commitment with the organizational citizenship behaviour among members of faculty in the Islamic Azad University-first district branches, in order to provide the appropriate model. Procedia-Social and Behavioural Sciences, 15, 306-310.

Sharma, D., Borna, S., \& Stearns, J. M. (2009). An investigation of the effects of corporate ethical values on employee commitment and performance: Examining the moderating role of perceived fairness. Journal of Business Ethics, 89(2), 251-260.

Si, S., \& Wei, F. (2012). Transformational and transactional leaderships, empowerment climate, and innovation performance: A multilevel analysis in the Chinese context. European Journal of Work and Organizational Psychology, 21(2), 299-320. 


\section{Macrothink}

International Journal of Human Resource Studies

ISSN 2162-3058

2020, Vol. 10, No. 4

Sungu, L. J., Weng, Q., \& Xu, X. (2019). Organizational commitment and job performance: Examining the moderating roles of occupational commitment and transformational leadership. International Journal of Selection and Assessment, 27(3), 280-290.

Suryanarayana, A. (2011, January). An empirical study into transactional and transformational leadership. In International Conference on Human Resource Management and Professional Development for the Digital Age (HRM\&PD). Proceedings (p. 58). Global Science and Technology Forum.

Tett, R. P., \& Meyer, J. P. (1993). Job satisfaction, organizational commitment, turnover intention, and turnover: path analyses based on meta-analytic findings. Personnel psychology, 46(2), 259-293.

Uçanok, B., \& Karabat1, S. (2013). The effects of values, work centrality, and organizational commitment on organizational citizenship behaviours: Evidence from Turkish SMEs. Human Resource Development Quarterly, 24(1), 89-129.

Vigoda-Gadot, E. (2007). "Leadership style, organizational politics, and employees' performance: An empirical examination of two competing models", Personnel Review, 36(5), 661-683.

Waldman, D. A., Bass, B. M., \& Yammarino, F. J. (1990). Adding to contingent-reward behaviour: The augmenting effect of charismatic leadership. Group \& Organization Studies, 15(4), 381-394.

Walumbwa, F. O., Wang, P., Lawler, J. J., \& Shi, K. (2004). The role of collective efficacy in the relations between transformational leadership and work outcomes. Journal of Occupational and Organizational Psychology, 77(4), 515-530.

Wang, P., \& Rode, J. C. (2010). Transformational leadership and follower creativity: The moderating effects of identification with leader and organizational climate. Human relations, 63(8), 1105-1128.

Whiting, S. W., Podsakoff, P. M., \& Pierce, J. R. (2008). Effects of task performance, helping, voice, and organizational loyalty on performance appraisal ratings. Journal of Applied Psychology, 93(1), 125.

Williams, L. J., \& Anderson, S. E. (1991) Job Satisfaction and organization commitment as predictors of organizational citizenship and in-role behaviours. Journal of Management, 17 (3): 601-617.

Wright, T. A., \& Bonett, D. G. (2002). The moderating effects of employee tenure on the relation between organizational commitment and job performance: a meta-analysis. Journal of applied psychology, 87(6), 1183.

Xerri, M. J., \& Brunetto, Y. (2013). Fostering innovative behaviour: The importance of employee commitment and org anisational citizenship behaviour. The International Journal of Human Resource Management, 24(16), 3163-3177. 


\section{Macrothink}

International Journal of Human Resource Studies

ISSN 2162-3058 2020, Vol. 10, No. 4

Yavuz, M. (2010). The effects of teachers perception of organizational justice and culture on organizational commitment. African Journal of Business Management, 4(5), 695-701.

Yukl, G. (1999). An evaluation of conceptual weaknesses in transformational and charismatic leadership theories. The leadership quarterly, 10(2), 285-305.

Zehir, C., Müceldili, B., \& Zehir, S. (2012). The impact of corporate entrepreneurship on organizational citizenship behaviour and organizational commitment: Evidence from Turkey SMEs. Procedia-Social and Behavioural Sciences, 58, 924-933.

\section{Copyright Disclaimer}

Copyright for this article is retained by the author(s), with first publication rights granted to the journal.

This is an open-access article distributed under the terms and conditions of the Creative Commons Attribution license (http://creativecommons.org/licenses/by/4.0/). 